\title{
Problematic Education Physical Students in the Wetlands
}

\author{
Herita Warni, Syamsul Arifin and Ramadhan Arifin \\ Department of Sport Education \\ Lambung Mangkurat University \\ Banjarmasin, Indonesia \\ hwarni@ulm.ac.id
}

\begin{abstract}
Learning of Physical Education in schools is often faced with the availability of facilities that are not adequate. From the observation of some schools, the majority of schools do not have adequate facilities and space to be able to do with a good physical education. This causes physical education process is not running optimally. In addition, physical education teaching practice should be done at least twice a week only once a week and things this was often constrained due to the tides that cause frequent physical education can not be done. The purpose of this study was to determine the level of physical fitness of students and problematics learning The environment wetlands. Research conducted Aluh-Aluh Subdistrict Banjar South Kalimantan, which has a specific area that wetland regions. the method is used is a blend qualitative with quantitative. As for the source of data in this research are: Qualitative Aspects tracked through the surrounding natural environment better school environment including learning models used by the teacher in the face of environmental challenges wetlands, family background, including the work of parents. In terms of a quantitative physical fitness test, students use the type of Indonesian Physical Fitness Test (TKJI) and measurement status nutrition learners. The results showed that infrastructure school-related sports facilities are very inadequate, while the dominant environment of wetlands causes learning education physical can not be established in optimal, In addition, it is also found that the nutritional status of poor learners dominant. From the dominant school environment wetlands and inadequate infrastructure for physical education are well organized, and on the other hand that the conditions of poor nutritional status also cause the level of physical fitness dominant learners category less.
\end{abstract}

Keywords: physical fitness, nutritional status, wetlands

\section{INTRODUCTION}

The total area of $37531 \mathrm{~km}^{2}$ of South Kalimantan, has two geographic features, namely the highlands and lowlands. Dominant lowland such as peat swamps and rivers of this kind is called a wetlands area with a total area of 382.272 ha. Wetlands according to the agreement The Ramsar Convention 1971 is defined as the area inundated by water that is naturally or artificially, either seasonal or constantly in a state of still or flowing water; water that flooded wetlands can be freshwater, brackish and salty; including the seafront waters with a depth not exceeding 6 meters at low tide conditions [1].

Natural conditions, of course, have limitations in conducting an activity that requires optimal space. Geographic location also affects the culture and customs. Children residing along the river course have the habit of playing with water, but it has limitations in activities such as running and games that require dry land to move. Likewise, with schools in such areas the average difficulty of organizing physical education class hours due to the tides, while the school does not have adequate facilities to perform well physical education activities.

Physical fitness can not be functional if someone poor nutrition. The nutritional status and body fat is a factor that affects the level of physical fitness, body composition associated with. Body composition is a picture of a person's body proportions are composed of fat, muscle, bone, and other tissues that results in total body weight [2]. Based on Health Research in 2018 was $17.7 \%$ underweight, $30,8 \%$ prevalence of stunting, and 10, $2 \%$ [3]. The prevalence of underweight. These nutritional problems are associated with the economic level of the parents.

The linkage between nutritional status and fitness level, of course, shows a positive relationship, but it is not always a good nutritional status will show the fitness status is also good. Some of the factors that affect a person's health status and fitness among others the setting of diet, rest, and exercise (Djoko Pekik Irianto, 2007)

Law of Republic of Indonesia of 2003 No. 20 on the national education system Article 37 explains that the curriculum of primary and secondary education must include 10 required fields contained in the curriculum. One of them is physical education and sport. In the explanation of the article states that physical education and sport studies are to establish the character of learners to be healthy physically and mentally, and foster a sense of sportsmanship. With the inclusion of physical education and sports, the field shows that the field is extremely important in human development in Indonesia.

Nevertheless, in fact, physical education in Indonesia has not been able to walk up to that due to limited infrastructure and supporting facilities for physical education can be held properly. Physical education is not just a form of physical fitness, but also affect the social, mental. The physical education as an educational process via the motion of human (human movement) which can be either physical activity, game or sport to achieve the purpose of physical education developed individual potential, full physical, intellectual, emotional, social, spiritual and moral [4]. Three are several contributions to physical education [5]. First, it can improve students' physical fitness and health. Second, improve the physical skills of the rich, and the third, it can improve student understanding of the principles of motion and how to apply them in practice.

From the description mentioned in the introduction, it can be argued that the purpose of this study was to determine the 
data are qualitative and quantitative. Qualitative data was tracked through observation interviews and document research. This method is done to track the natural environment better school environment including learning models used by the teacher in the face of environmental challenges wetlands, family background, including the work of parents. Quantitative data being physical fitness test students use the type of Indonesian Physical Fitness Test (TKJI) and measurement status Nutritional learners totaling 100 people. The summary of the approach and method instrument can be seen in Table 2. elementary schools in the district-Aluh Aluh Banjar district in October to December 2018. Data collected in the two types of

TABLE I. APPROACH METHODS AND INSTRUMENTS

\begin{tabular}{|c|c|c|c|c|c|}
\hline \multicolumn{6}{|c|}{ Method } \\
\hline \multicolumn{3}{|c|}{ Qualitative } & \multicolumn{3}{|c|}{ Quantitative } \\
\hline Type & Suber Data & Instrument & Type & $\begin{array}{c}\text { Data } \\
\text { source }\end{array}$ & Instrument \\
\hline \multirow[t]{2}{*}{ Environment } & $\begin{array}{l}\text { - The neighborhood } \\
\text { around the school } \\
\text { - Teacher }\end{array}$ & $\begin{array}{l}\text { researchers themselves } \\
\text { - Observation } \\
\text { - Interview }\end{array}$ & physical fitness & Learners & $\begin{array}{l}\text { TKJI } \\
\text { Age } 16-19 \text { Years } \\
1313-15 \text { years of age } \\
\text { Age } 10-12 \text { years }\end{array}$ \\
\hline & - Fasilitas school & $\begin{array}{l}\text { researchers themselves } \\
\text { - Observation }\end{array}$ & status nutrition & Learners & $\begin{array}{l}\text { Measurement of Nutritional } \\
\text { Status } \\
\text { age } 16-19 \text { years } \\
\text { age } 13-15 \text { years } \\
\text { Age } 10-12 \text { Years }\end{array}$ \\
\hline $\begin{array}{l}\text { Teacher } \\
\text { readiness }\end{array}$ & Physical Education Teacher & $\begin{array}{l}\text { Document Analysis Learning } \\
\text { Tool }\end{array}$ & & & \\
\hline
\end{tabular}

\section{RESULTS AND DISCUSSION}

The data in this study is divided into two parts, the data derived from qualitative data sources, and the research data in the form of quantitative data.

\section{A. Qualitative Data}

The data shown in the qualitative survey is the result of inductive analysis of data from interviews, observation, and study of the document, which is presented alternately and support each other in accordance with a focus to answer research questions.

\section{1) Environment Schools and School Facilities.}

Picture of the school environment traced through interviews and observations at the data source. The observation started from the observation state school environment. The observations found that the condition of the school is in an environment of wetlands. The average building is built on low-lying land flooded, resulting in around school seems very stagnant water caused by tidal water. Such conditions have occurred in almost all schools in sub AluhAluh Banjar district totaling 37 schools of State, made up of levels of State Elementary School (SDN) amounted to 26 schools, the level of Junior High School (SMPN) amounted to 8 school, school level Government Secondary Up (SMAN) numbered 1 School. The focus of research conducted in three schools, comprising 1 elementary school, 1 Secondary school, and one high school. From interviews with teachers (A1), he stated that "Here the tides, and if the current rainy season then it is likely the whole neighborhood/schoolyard flooded". Likewise expressed by A2, "although tidal water is occurred at night, in the morning it still can not be used because the field is still muddy". Later asked by investigators, "If so how student activity when it breaks with wet environmental conditions like this? "Yes terrace house environment, because it is impossible to play outside" replied A1. "Although water is high tide at night, in the morning it still can not be used because the field is still muddy". Later asked by investigators, "If so how student activity when it breaks with wet environmental conditions like this? "Yes terrace house environment, because it is impossible to play outside" replied A1. "Although water has a high tide at night, in the morning it still can not be used because the field is still muddy". Later asked by investigators "If so how student activity when it breaks with wet environmental conditions like this? "Yes terrace house environment, because it is impossible to play outside" replied A1.

From interviews and observations, it can be noted that the school environment is often stagnant water caused by tidal water, even when the rainy season, the whole neighborhood would be inundated. Such things certainly inhibit the activity of the students, especially when teaching physical education.

\section{2) The Facilities and the Readiness of Teachers to Prepare} Lesson

From observations and interviews, it is also found that facilities for teaching physical education were minimal; both open field and room that can be used for physical education teaching. Presented by one of the teachers (A2) that at school they do not have the grounds and rooms, until when physical learning, learners often invited out to the street. Even during the rainy season sometimes move to teach physical education teachers in a classroom, but it certainly can not run maximum learning because of limited space. From the observations made by researchers to the school (S1), when teachers teach gymnastics lessons done in the classroom narrow, so that seems learners are not free to move. Such conditions are of course an obstacle to learning Physical Education. When the interview in indentations in high school, researchers asked about their efforts to solve environmental problems wetlands 
nfrastructure are an important resource and a major in

that inhibit the activity of teaching physical education. Presented by A3, that they have made a stage on wetlands for playgrounds and sports for students. From the observation does seem a stage resembling a basketball court built high enough above the wetland, measuring approximately $10 \times 24$. The field is what is used to perform various activities including physical education teaching. From interviews and observations can be argued that learning physical education can not take place optimally,

Learners living environment is also not much different from the school environment, namely the area flooded wetland because of tides, and even when the rainy season, the area around the yard of the house was also flooded. Such conditions can not make the students move well when I was at home because it has no open space for play. Many activities carried out by them just watching TV and playing HP. Average work the majority of parents are farmers, fishermen, and only a small part as an ASN (State Civil Apparatus)

From interviews and document studies, it is found that on average teachers with Bachelor (Tier 1), still have not been certified. When conducting observation and document study about the ability and readiness to teach physical education teacher was found that teachers do not prepare welllearning devices except RPP does not yet reflect the application of K13. However, when examined RPP that is on them is still using the old curriculum. This condition may illustrate that the ability of physical education teachers in the preparation and conduct of teaching is not maximized.

\section{B. The Quantitative Data. 1) Physical fitness}

TABLE II. PhysicAl FitNESS TEST AND NUTRITIONAL STATUS

\begin{tabular}{|l|c|l|c|}
\hline \multicolumn{2}{|c|}{ Level Fitness } & \multicolumn{1}{c|}{ Nutritional status } \\
\hline \multicolumn{1}{|c|}{ Status } & $\%$ & \multicolumn{1}{c|}{ Status } & $\%$ \\
\hline Well & 8.69 & obesity & 17.80 \\
\hline moderate & 33.63 & overweight & 20.28 \\
\hline Less & 46.73 & good nutrition & 40.66 \\
\hline Less than Once & 10.95 & Malnutrition & 18.96 \\
\hline & & Malnutrition & $2: 30$ \\
\hline & 100 & & 100 \\
\hline
\end{tabular}

Facilities and infrastructure are important in the learning process of physical education. Without an adequate infrastructure for physical education, student learning will not run properly, so the purpose of physical education will not be achieved. Listening to the Government Regulation of National Education No. 24 of 2007 Article 1 reads standard of facilities and infrastructure for primary schools / madrasah (SD / MI), junior / MTs (SMP / MTs), and high school / madrasah aliyah (SMA / MA) include minimum criteria for facilities and infrastructure minimum criteria. With these regulations it should all schools should have such standards.

One is supporting the success of physical education facilities and infrastructure, if any, in accordance with the number and needs of students. Achievement of the objectives of physical education is influenced by several factors, including teachers, students, curriculum, facilities (sports equipment), infrastructure (sports facilities), environmental, and social. From the analysis of field data, it can be argued that learning physical education can not take place either due to environmental constraints wetlands. Facilities and supporting teaching and learning in schools are minimal. School standards for sports facilities not in accordance with the standards of facilities and infrastructure candy No. 24 of 2007. With a lack of infrastructure such as how the physical education learning process can proceed smoothly. Infrastructure is complete and sufficient to support successful learning achievement of the objectives of physical education in the optimal physical education.

Nutritional problems may also be a problem, recorded $59.44 \%$ ranks of overweight and malnutrition, only 40, 46 which have good nutrition. This condition, of course, affects the physical fitness of students. To be able to have good physical fitness needed a good nutritional status as well. It can be argued that the better the nutrition a person, the better the physical fitness [7].

With the ups and downs of natural conditions, infrastructure is inadequate, and poor nutritional status tends, indeed hope to be able to obtain the physical fitness of students will not be achieved. These conditions require the attention of the local government from all sides. Fulfillment of adequate infrastructure and media infrastructure facilities for the school absolutely must be done, so that learning physical education can work well and meet the criteria of good quality. Poor nutritional status also needs great attention, how to make people aware of the importance of good nutrition.

\section{CONCLUSION}

From the results of research and discussion can be concluded that: (1) Learning physical education in school Subdistrict Aluh-Aluh often experiences problems resulting wetland environment that is tide receding; (2) Supporting facilities for physical education learning activity is still very low; (3) The creativity of teachers in creating innovative learning to address learning problems of physical education in order to depart the optimal walk is still very minimal; (4) 17.80 There is a good nutritional status, nutritional status is currently 20.28, and 61.92 are on malnutrition until the bad; and (5) Conclusion $1.2,3$, and 4 can be suspected cause of fitness level learners, reaching only $8.9 \%$ have a good category. However, further research is needed.

\section{ACKNOWLEDGMENT}

We would like to be grateful to the Dean of Teacher Training and Education Faculty, Lambung Mangkurat University, who has supported us in the form of funding. Therefore we could join this International Conference.

\section{REFERENCES}

[1] Ari, "Penjelasan Lengkap Sejarah Konvensi Ramsar Beserta Isinya," 2019.

[2] F. Sizer and E. Whitney, Nutrition Concepts and Controversies, 10th ed. Victoria: Thomson Wadsworth, 2005.

[3] I. Astuti, "Riset Kesehatan Nasional 2018: Angka Stunting Turun," Media Indonesia, 2018.

[4] R. Lutan, Pendidikan Kebugaran Jasmani: Orientasi Pembinaan Di Sepanjang Hayat. Jakarta: Dirjen Pendidikan Dasar dan Menengah Dirjen OR, 2002.

[5] P. Dauer, Dynamic Physical education for Elementary Scholl Children, 11th ed. Boston: Allyn and Bacon, 1995.

[6] J. . Creswell, Research Design Qualitative, Quantitative and Mixed Methods Approaches. California: Sage Publications, 2009.

[7] S. Saparinah, Psikologi Olahraga Dan Buku Tuntunan. Jakarta: Pusat Kesehatan Jasmani dan Rekreasi: Depdikbud, 1982 